\title{
Szabó Panna
}

\section{HANGTANI VIZSGÁLATOK A KENYÉR PÉLDÁJÁN \\ A MAGYAR NYELVTERÜLET NYUGATI FELÉNEK NYELVATLASZAI ALAPJÁN*}

\begin{abstract}
Panna Szabó: Phonetic studies using the example of kenyér ('bread') based on the language atlases of the western part of the Hungarian speaking area

With the help of the list of the network of points of research, and that of the entry words of the language atlases covering the Hungarian language speaking area, it is possible to find out which atlas included a given word, and where they have recorded it. The study examinesthree linguistic phenomena using the example of kenyér (bread): the appearance the relation of the first vowel e: i open-closed and e: ö illabial-labial, and the use of $i$ in the second syllable. The sources of the study were the following maps: MNyA. 1029, NyvA. 59, MurA. 38, ÖHA. No. 15, SZA. 230, ZsA. 38, JBarA. 18 and SzlavA. 29.
\end{abstract}

A magyar nyelvterület nyelvjárási jelenségeit megőrző nyelvatlaszok egyesített kutatópont-hálózatának és címszójegyzékének elkészítése (SzABó 2018), valamint egy térképgeneráló szoftver rendelkezésre állása (vö. SzABó 2018: 93-97) elösegítheti, hogy a nyelvatlaszokban eddig különálló nyelvi adatokat gördülékenyebben egymásra vetítve könnyebben képet kaphassunk a vizsgált földrajzi terület nyelvi jelenségeiről, illetve az atlaszok gyüjtési idejének függvényében azok esetleges változásairól.

A nyelvi jelenségek mozgásának vizsgálatában a nyelvatlaszok fontosságára sokan sokféleképpen felhívták már a figyelmet (a teljesség igénye nélkül ld. például Deme 1999, 2004, Hegedüs 2004, 2008, JuHÁsz 2007), emellett:

Nyilvánvaló: ahol vannak nyelvatlaszok, különösen a nagyobb területet lefedők, ott azok kitüntetett fontosságú források. Erre következtethetünk azokból az észrevételekböl, megállapításokból is (átfogó, tüzetes

* A vizsgálat elkészítéséhez nyújtott értékes tanácsaiért köszönettel tartozom JuHÁsz Dezsőnek. 
vizsgálat még nem készült egyik esetben sem!), amelyek a nagyatlasz után megjelent magyar regionális atlaszok bevezetőiben olvashatók arról, hogy a nagyatlasz és a később készült regionális atlaszok megegyező kutatópontjain az azonos kérdésekre más időpontokban kapott válaszok eltérései mit mutatnak.

- írta KISs JENŐ az új magyar nemzeti nyelvatlasz szükségessége mellett érvelö tanulmányában (KIss 2006: 134). A kurrens szakirodalom alapján azonban megfigyelhető, hogy egyes magyar régiók nyelvatlaszai gyakrabban jelennek meg korpuszként a vizsgálatokban. Ennek többféle oka lehet, például egy új kiadvány megjelenése, amely ráirányítja a figyelmet az adott területre és a kutatási lehetőségekre; vagy kerülhetnek be nyelvatlaszok integrált adattárakba, adatbázisokba teljes anyagukkal együtt, optimálisabb lehetőségét teremtve meg átfogó vizsgálatuknak. A magyar nyelvterület nyugati felének atlaszaira ez eddig nem volt jellemző, ezért figyelmemet elsősorban a Duna észak-déli vonalától nyugatra fekvő kutatópontokkal is rendelkező 12 dunántúli és egy felvidéki magyar nyelvatlaszra fókuszálom.

A nyelvatlaszok adataira alapozva hagyományosan egyaránt végezhetők hangtani, alaktani és lexikai vizsgálatok. E tanulmány ${ }^{1}$ keretein belül hangtani szempontú vizsgálatra a magyar nyelvterület nyugati felén 8 nyelvatlaszban is kikérdezett kenyér címszót választottam ki. Forrásaim ennek megfelelően a következő atlaszlapokból állnak: MNyA. 1029, NyvA. 59, MurA. 38, ÖHA. 15, SZA. 230, ZsA. 38, JBarA. 18 és SzlavA. 29 (ahol a nyelvatlasz rövidítését a kenyér címszavú térkép száma követi).

Részben a kenyér címszó magas ismétlődésének a nyelvatlaszokban, részben hangtani sajátosságainak köszönhetően is többféle vizsgálat végezhetö rajta. Ezek közül az első magánhangzó $e$ : $i$ nyílt-zárt, illetve $e$ : $\ddot{o}$ illabiálislabiális viszony megjelenését; valamint a második szótagbeli $i$-zést választottam ki.

A címszó nyolc nyelvatlaszban elöfordulása, a sok adat miatt az egyesített térképlapokon az adatbeíró technikáról le kellett mondanom. Helyette különböző színekkel megfeleltetve mutatom be a vizsgált nyelvi jelenségek elterjedését, és emellett a következőkben közlöm a vizsgálatok alapjául szolgáló térképeken fellelhető nyelvi adatokat is.

1 A vizsgálatok SZABÓ 2018 nyomán. 
1. kenyér (MNyA. 1029): [kenyér] Cssz-2. - [kenyér] Cssz-2. - <kënyiér> C-23, C-26, E-11, F-19. - <kënyír > Cssz-13, A-1 - - <kënyír > Cssz-11. - kënyiër B-3, B-18. - kënyér Cssz-15-16, B-32, C-16, C-23-26, D-3-4, D-13, D-16, D-37, E-12, E-15-16, F-9, G-5, G-12. - [kënyér] D-12, F-13. - <kënyér> B-34. [kënyér] D-28. - kënyìr Cssz-14. - kënyeér G-10. - kënyér D-11, G-8. - këny ér F-4, G-12. - kënyyiër G-11. - kënyér Cssz-8, Cssz-10-11, Cssz-13-15, A-3, B-30, C-2-4, C-6-7, C-10-12, C-15-19, C-21-22, C-25, D-2, D-4-10, D-15, D-18-19, D-32-34, D-36, D-38, E-3-8, E-11-15, F-1-2, F-7, F-10, F-18-21, G-2, G-4-6, G-9. - kënyèr F-13, F-17. - kënyer F-8. - kënyér A-1, C-1, 7, 9, 16. - kënyiér A-13, A-33, B-11, B-13, B-15, B-28, B-37, C-6, C-13, C-15, C-19, D-33. kënyi er A-4. - kënyi er A-6, A-25. - kënyiër Au-1, Au-3-4, A-5, A-7-9, A-14, A-16, A-18, A-20-21, A-23-24, A-26, A-30, A-32, B-2, B-5, B-8, B-10, B-12, B-14, B-17-19, B-21-23, B-25, B-27, B-29, B-31, Ju-1, C-5, 13, D-1. - kënyiẹr A-2, A-10-12, A-15, A-17, A-19, A-22, A-26-29, A-31, A-34, B-1, B-6-7, B-9, B-16-17, B-20, B-24, B-26, C-6, C-14. - kënyiër A-24, B-2, C-13, C-17. - kënyir Cssz-3, Cssz-7, Cssz-11-12, Cssz-14. - kënnyiër Au-2, A-30, B-3-4, B-19, B-25. - kënny ér B-9. - < kënnyiër $>\mathrm{Au}-3$. - kënyệr C-8. - kënyéir G-7. - kënyér G-3. - <kennyér > F-4. - kënyér D-5. - kënyér D-17, D-31. - <kënyéir > G-7. $<$ kënyér > G-3. - kinyér F-14-15. - könyér B-33. - <könyér > B-30. - kinyér Cssz-1-2, Cssz-4-6, Cssz-8-9, Cssz-13, E-5. - kinyér E-5. - <kinyir > Cssz-2. kanyer F-16. - könyer F-16. - könyér $\mathrm{D}-29$. - <könyér $>\mathrm{D}-31-32$, D-36. - könyềr Ju-2. - könyeёr B-36, D-27. - könyér D-20. - könyēir D-22. - könyér $r$ D-25-26. könyér B-34-36, D-12, D-14-15, D-19-21, D-23-24, D-27-28, D-30, D-35, E-17, F-5, G-1. - könyè्̆r Ju-2.

2. kenyér (NyvA. 59): kinyír 2. - kënyér 20. - kënyír 1, 4, 6-16, 18-19, 21-26. - kinyér 1, 3-5, 14-21.

3. kenyér (MurA. 38): kënyér 4. - kenyiêr 7-8. - kenyiër 12, 19. - kenyiër 1, 15-16. - kenyiér 2, 5. - kenyier 3, 6, 10-11, 13-14, 17-18, 20. - kënyier 9.

4. kenyér (ÖHA. 15): < [kënyérr]> 13. - <kënyéir> 6. - kënyyièr 34, 41-42. këny $y^{i} \ddot{e ̈ r} 43$. - kënyiềr 1, 8-9, 19-20, 22. - këny érr 33. - kënyièr 10-12, 17, 23-24, 27-28, 32-38, 40, 45-47. - këny'ér 25, 33, 39. - kënyiër 32, 37, 41, 43-44. [kënyièrr] 13, 16. - kënyiër 2, 3, 5, 7, 30-31, 44. - kënyìr 6. - kënyiër 1-5, 8-12, 14, 18, 20-22, 27. - këny ề r 26, 28, 39. - kënnyièr 15, 18-19, 39-40, 42, 46. kënny ër 29. - kënnyiër 14-15, 19, 22, 30-31. - kënnyie्रिr 29. - kënnyièrr 3-4, 7, 13-14, 16, 23, 27, 45, 47. (kënnyiềr) 17. 
5. kenyér (SZA. 230): (kënyér) 83-84. - < kënyier > 14. - kënyéir 34-35, 75, 80, 93. - kënyér 5, 17, 23-24, 28, 33, 37, 39, 42-44, 59-64, 70-72, 76-78. [kënyér] 8. - këny'ér 1-7, 9-16, 19, 22. - kënyiër 2. - kënyiër 8, 18. - kënyi ềr 3, 7, 13, 22. - kënyér 20-21, 23, 27-29, 31-32, 35, 38, 40, 47, 64-68, 73, 75. könyéér 58, 99. - könyéi 41, 48, 81, 83-85. - <kënyéir > 91. - kënyéir 46, 87, 93. - kënyér 20, 52-53, 75. - këny'ér 18. - <kënyiér> 7. - kënyér 25. - <kënyér $>$ 24. - könyér 25, 36, 41-47, 49-53, 56-57, 69, 71, 74, 79-80, 82, 86-87, 89-90, 92-93, 96-99. - (könyér) 68. - könyér 48. - könyiër 22. - könyér 30, 54. $<$ könyếr > 9. - könyẹ́i $55,91,94-95,97$. - könyẹrr 88. - könyér 17, 25, 49, 71, 90 . könyiér 20, 32. - könyérr 26, 47-48, 67, 79.

6. kenyér (JBarA. 18): kënyér 1, 3, 6. - kenyér 2. - kënyír 7. - kënyir 9. kenyir 4-5. - kenyirke 8. - kënyirke 8. - kinyér 10. - (kinyér) 1.

7. kenyér (SzlavA. 29): kënyér 1, 5, 11. - kinyér 3. - kinyéér 8. - könyéir 10. - kinyéirir 2, 4, 6-7, 9. - [kinyer] 6-7.

8. kenyér (ZsA. 38): kënyér 1, 6-7, 10, 12, 14, 36, 42, 44-45. - könyér 2-4, 8-9, 13-15, 17-19, 21-24, 26, 28, 31-32, 35, 37-39, 41, 43, 46-56. - könye ér 2, 8, 18, 21, 25-27, 30. - kọnyér 3, 23-24, 35, 44. - könyẹr 5, 11, 20, 23, 29, 34, 40. - kënye ér 16. - könyeér 20, 31, 33. - prót 36.

Az első szótag magánhangzója, e > i, e > ö

A kenyér első szótagbeli köznyelvi $e$ nyelvjárási $i$ zártsági viszonyt, valamint az $e \sim \ddot{o}$ labiális viszonyt a nyolc atlasz egyesített atlaszadataiból készített térképlap szemlélteti (ld. 1. térkép). A kenyér szóban az előzetesen ismert és várt alaptétel szerint mindkét irányú hangváltozás él a magyar nyelvterület nyugati felén, ami igazolódik a nagyatlasz és a hét regionális atlasz adatai alapján.

Elsőként nézzük meg nagyatlaszbeli előfordulásokat! A köznyelvi $e$-nek $\ddot{e}$ hangváltozatát kék, az $\ddot{o}$-t piros, az $i$-t sárga színnel láthatjuk. Ahol több adatot is feljegyeztek, előfordul, hogy az első szótag magánhangzójában különböző két alak él egymás mellett. Az $\ddot{e}$-s és $\ddot{o}$-s alakváltozatot egyaránt használó települések lila, az ë-s és i-s kutatópontok zöld jelölést kaptak.

(Lásd az 1. térképet a cikk végén!)

A nagyatlasz nyugati magyar nyelvterületi adatai alapján az ë elterjedtsége a nyelvterület jelentős részén domináns. A labializálódás a Dél-dunántúli nyelvjárási régióra erőteljesen jellemző, ë-s alakokat csak az ë és ö ütközőzóná- 
jában, az $\ddot{o}$-s alakokkal együtt élve találunk (ld. a lila színnel jelölt kutatópontokat), a régión belül nem. A nyelvterület északi pontjain látunk a köznyelvihez képest zártabb, $i$-s alakokat, Rétén, Barslédecen, Nagyhinden, Csütörtökön és Zsitvabesenyőn; valamint Tolna megyében az F-14-es kutatóponton, Decsen és az F-15-ös Alsónyéken. Szintén északon, az ë-s és $i$-s alakok találkozásánál rajzolódik ki egy északnyugat-délkelet irányú átmeneti zóna, ahol mindkét változat él. A nagyatlasz jellegéből adódóan átfogó képet kíván adni. Nézzük meg, hogyan változik a kenyér első magánhangzójának helyzete, ha rávetítjük a regionális atlaszokat!

\section{(Lásd a 2. térképet a cikk végén!)}

Figyelmünket az ütközőzónákra kell irányítani, mert ott várható, hogy a regionális atlaszok árnyalják, vagy az eltérő gyüjtési idők miatt módosítják a nagyatlasz alapján levonható megállapításokat. A regionális atlaszok adataival együtt pontosabban kirajzolódik az $\ddot{o}$-ző terület nyugati felén az ë-s régióba nyúló nyaláb határvonala, valamint ennek peremén azok a kutatópontok, ahol mindkét változat él. Az $\ddot{o}$-s elöfordulás legnyugatibb pontja a kenyér adatai alapján Nagykanizsa.

Az északi területen jellemző zártabb, $i$-s alakok északnyugat-délkelet irányú átmeneti zónájának északi részén, a Nyitra-vidéken legerősebb a két alak egymás mellett élése. Ugyanitt, a terület közepén, egy összefüggő magként megfigyelhető a köznyelvi $e$-s hangváltozat góca. A területet elsősorban peremhelyzetekben néhány csak $i$-s formát használó település veszi körbe. Tisztán az $i$-s alakok használata jelenik meg továbbá a vizsgált terület legdélebbi részén, a SzlavA. déli kutatópontjain.

A két térképlapot összevetve négy olyan települést találunk, ahol a később gyüjtött regionális atlaszok módosítják, árnyalják a MNyA.-ban láthatókat.

1. MNyA. B-30 és SZA. 17, Galambok: az ö-ző terület nyugati szélén a nagyatlasz gyüjtési időpontjában az $\ddot{e}$-s és $\ddot{o}$-s alak egyaránt fellelhető volt. Az $\ddot{o}$-s a MNyA.-ban „ritkán használt alak” minősítést kapott, és a SZA. gyüjtési időpontjában már nem is volt azonosítható.

2. MNyA. D-12, SZA. 45 és ZsA. 3, Mesztegnyő: a nagyatlasz gyüjtési időpontjában az $\ddot{e}$-s és $\ddot{o}$-s alak egyaránt fellelhető volt, de az $\ddot{e}$-s alak „újabb/terjedő alak” minősítést kapott. Ennek ellenére a SZA. és a ZsA. szerint is már csak az $\ddot{o}$-ző változat él, tehát az $\ddot{e}$-s alak nagy valószínüséggel nem gyökeresedett meg, vagy annyira ritka, hogy egyik regionális atlasz gyüjtésekor sem volt fellelhető. 
3. MNyA. D-14, SZA. 93, Somodor: a nagyatlaszban feljegyzettek szerint a településen csak az $\ddot{o}$-ző alak él. A SZA. gyüjtési időpontjában, körülbelül 20 évvel később az $\ddot{o}$-ző mellett az ë-s változatot is rögzítették.

4. MNyA. B-37, SZA. 22, Nagykanizsa: a nagyatlasz adatai alapján a Nagykanizsától északra és délre fekvő településeken is megjelent már a kenyér szó első magánhangzójának mindkét hangváltozatú formája, de Nagykanizsán még csak az ë-s változatot jegyezték fel. Húsz évvel később, a SZA. gyüjtésekor már mindkét hangváltozatú alak fellelhető volt. Ez jelezheti egyrészt az $\ddot{e}$-s mellett az $\ddot{O}$-s megjelenését, vagy azt, hogy a regionális atlasz gyüjtése mélyebb volt, és sikeresen feltárt egy ritkábban tetten érhető alakváltozatot.

\section{Az i-zés a magyar nyelvterület nyugati felén a kenyér példáján}

A kialakulásának oka és a helyettesített hang alapján a szakirodalom az $i$-zés különböző típusait különbözteti meg (vö. IMRE 1971). A kenyér címszó második szótagjának példáján a köznyelvi é helyén megjelenő $i$-zés, valamint a nyitódó és záródó diftongusok elterjedtségét vetítettem térképre.

\section{(Lásd a 3. térképet a cikk végén!)}

A MNyA. adatai alapján készült áttekintésben a hangalakok normalizálása után az $i$-ző alakokat citromsárga, a köznyelvi é-t sötétkék, az e-t fekete, a nyitódó ie diftongust piros, az ei-t szürke színnel jelöltem. Az olyan kutatópontokat, ahol több, egymástól eltérő hangalakú változatot is rögzítettek, $i$-s és é-s alakok együttállása esetén zöldre, köznyelvi é és ie együttes megjelenésekor lilára, é és $e^{i}$ félhangzós alakokat barnára színeztem. A csökkentett nyomatékú elemmel rendelkező hangpárokat a megfelelő diftongussal számítottam egybe.

A nagyatlasz adatai alapján az $i$-ző formájú kënyír kizárólagosan mindössze három településen lelhető fel: Martoson, Nyitragerencséren és Nemeshódoson, a mai Szlovákia területén. A köznyelvi é-s kënyér előfordulásokkal párhuzamosan további öt kutatóponton jegyezték fel, Dunakilitin, Izsapon, Nagyölveden, Ebeden és Vágán.

Mind az északi részen az $i$-ző alakok mellett, mind a magyar nyelvterület nyugati felének jelentős részén, észak-déli irányban végig a Duna vonalától a Közép-dunántúli-kisalföldi és a Dél-dunántúli nyelvjárási régiók nyugati határsávjáig a köznyelvi é hang, a kënyér és könyér forma a domináns, függetlenül az első szótag labiális vagy illabiális helyzetétől.

A nagyatlasz adatai alapján a nyugat-dunántúli régióban kizárólag nyitódó ie diftongust hordozó szóalakokat jegyeztek fel. Ennek a területnek az északke- 
leti részén, a köznyelv é-s régió pereme mentén a Kajárpéc, Vanyola, Nyárád, Somlóvásárhely észak-déli tengelyen rajzolódik ki az az ütközési zóna, ahol a két változat egymás mellett él. A Balaton északkeleti csücskében, Felsőörsön és Fülén szintén feljegyezték mindkét alakot, de a kënyiér $i$ hangzóját már csak csökkentett nyomatékú elemként.

A nyitódó diftongus mellett néhány kutatóponton a záródó ei-s kënyeir formát találjuk, összefüggő területi egységet alkotva Baranya déli részén Old, Cún és Kovácshida településeken. Töle északra, Somogyban szintén három kutatóponton jegyezték fel ezt a hangváltozatot, Marcaliban, Kisasszondon és Kaposkeresztúron.

A köznyelvi é $\sim$ nyelvjárási $e$ hangmegfelelés a legritkább jelenség a kenyér második szótagbeli magánhangzójának hangváltozásai közül, mindössze a MNyA. F-16-os és F-8-as kutatópontján, Zengővárkonyban és Kétyen azonosítható.

Nézzük meg, hogyan változik a térképlap, ha a hét regionális nyelvatlasz adatait is rávetítjük!

\section{(Lásd a 4. térképet a cikk végén!)}

Ha a nyolc atlasz térképlapjait egyesítjük, a fenti kép rajzolódik ki. A többféle alakváltozatot is felsoroló településeken a már ismert együttállásokon kívül három olyan kombinációt is találunk, amelyre a nagyatlaszban nincs példa. Ezek a következők: 1 . $i$-ző és e ei-s alakváltozat (ÖHA. 6, Farkasfa; a térképen narancssárga); 2. köznyelvi é, e ei-s és ie hármas együttállás (SZA. 48, Nemesvid; a térképen türkizkék); 3. e-s és ei -s hangváltoztató alakok (SzlavA. 6-7, Kórógy és Szentlászló 2; a térképen rózsaszín).

A nagyatlasz és a regionális nyelvatlaszok adatai alapján az í-ző formájú kënyír északi nyelvföldrajzi képe nem módosul jelentősen. Nyitrától északkeletre, Kolon, Alsócsitár, Pográny központtal rajzolódik ki a jelenség centruma, és körülötte, egyre távolodva fokozatosan jelennek meg a tisztán $i$-ző alakok mellett az $i$-ző és é-s formát egyaránt használó települések. A tőle délnyugatra fekvő Nemeshódos és Marton településeket már egy é-ző sáv választja el a góctól. A kenyér második szótagjában $i$-t használó települések jelennek meg a magyar nyelvterület nyugati régiójának déli részén is, a JBarA. kutatópontjain, egy összefüggő észak-déli irányú sávot alkotva.

A nagyatlasz kijelölte föbb határokkal összhangban rajzolódik ki a köznyelvivel egyező é használata is. Somogyban a MNyA. három kutatóponton jegyzett fel ei formát. Ezt a húsz évvel későbbi gyüjtési idejü Somogy-zalai nyelvatlasz jelentősen árnyalja, a Közép-somogyi csoportban tíz településen - Marcaliban, Gadányban, Libickozmán, Pusztakovácsiban, Mernyén, Rák- 
siban, Igalon, Bodrogban, Somodorban és Somogysárdon - is feljegyezve a köznyelvi é mellett a záródó $e^{i}$ félhangzós alakot is. Az összefüggő é-ző területtől távol, a magyar nyelvterület nyugati peremén a MurA.-ból azonosítható e vizsgált szó tekintetében egy külső nyelvjárásszigetként megjelenő település, Pártosfalva.

A Nyugat-dunántúli régió nyitódó ie diftongusainak egységét Pártosfalván kívül egy nyelvjárássziget, az ÖHA. 6-os kutatópontja, Farkasfa is megbontja. Itt, a környezetétől eltérően, záródó diftongust és $i$-ző alakot egyaránt feljegyeztek, Farkasfa tehát nyilvánvalóan nyelvjárássziget. Töle délkeletre, Ispánkon a nyitódó diftongus mellett a köznyelvi é-s alakváltozatot is azonosították. A nyitódó ie diftongussal jellemezhető terület északkeleti határsávját nem módosítják, árnyalják a regionális atlaszok, mivel itt változatlanul csak a MNyA.-ra hagyatkozhatunk. A délkeleti vidéken a magas kutatópontszámmal dolgozó SZA. van segítségünkre a határsáv megvonásában, a nyitódó diftongusos terület legszélső pontját Zalakomárnál jegyezve fel.

Szintén a SZA.-nak köszönhetően jelenik meg egy egyedi elöfordulási kombinációt jegyző település, a háromféle hangváltozatú alakot is felsoroló Nemesvid (SZA. 48). Itt az é-s forma mellett a csökkentett nyomatékú $i$ elem az $e ́$ elötti és utáni pozícióban is megjelenik.

A nagyatlasz adataihoz képest szintén újdonságként jelentkezik a SzlavA. 6-7. kutatópontján, Kórógyon és Szentlászlón az e-s változat mellett megjelenő éi-s hangváltozatú alak.

A regionális atlaszok a nagyatlasszal közös kutatópontjaikon általában ugyanolyan hangváltozatú alakokat sorolnak fel. A négy kivétel a következő:

1. MNyA. Cssz-5 és NyvA. 15, Nagyhind: a nagyatlasz gyüjtési időpontjában csak a köznyelvi é-s változatot jegyezték fel, míg a körülbelül 30 évvel későbbi NyvA.-ban az $i$-ző alakot is.

2. MNyA. B-29 és SZA. 8, Gelsesziget: a MNyA. csak nyitódó diftongusos, a húsz évvel később gyüjtött SZA. emellett köznyelvi é-s alakot is mutat.

3. MNyA. D-11 és SZA. 35, Marcali: a MNyA.-ban is olvasható $k_{e ̈ n y e ́ r} r$ mellett a SZA. az é hangalakú változatot is közli.

4. MNyA. D-14 és SZA. 93, Somodor: a MNyA. könyér változata mellett a SZA-ban a kënyér jelenik meg. 


\section{1. térkép}

MNyA.: kenyér (köznyelvi e nyelvjárási $i$ zártsági viszony)

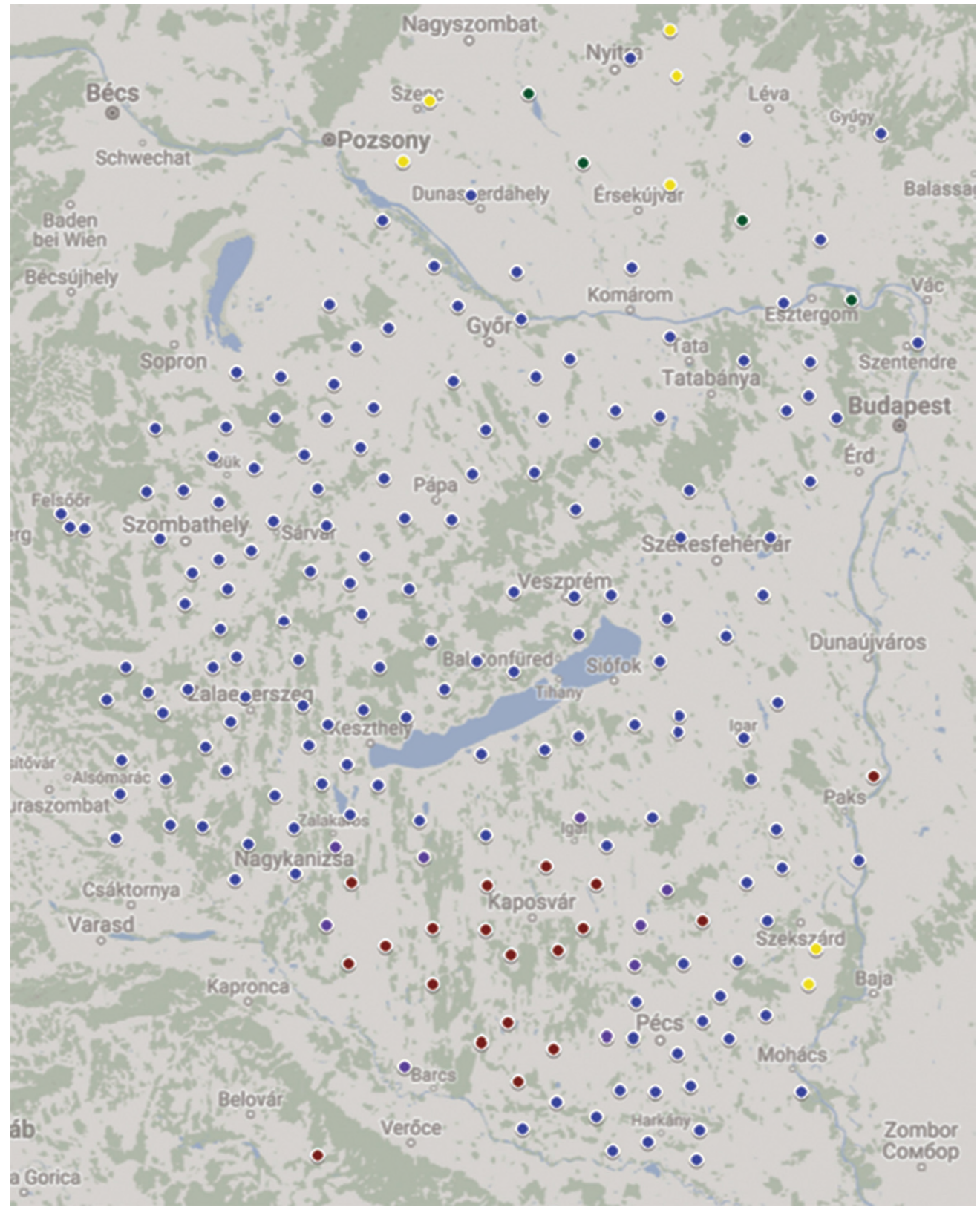




\section{2. térkép}

MNyA. és regionális atlaszok: kenyér (köznyelvi e nyelvjárási $i$ zártsági viszony)

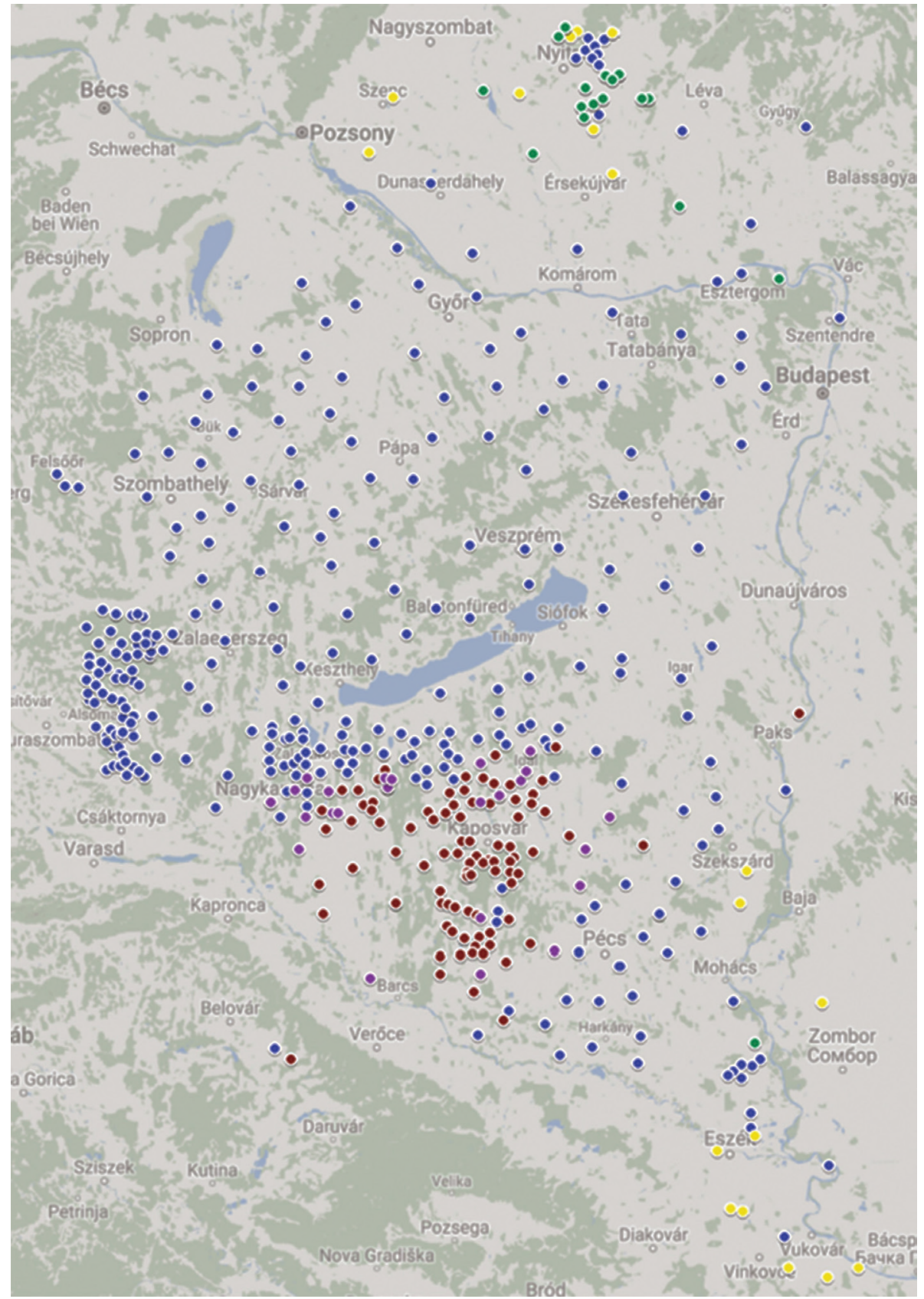




\section{3. térkép}

MNyA.: kenyér (köznyelvi é helyén megjelenő $i$-zés)

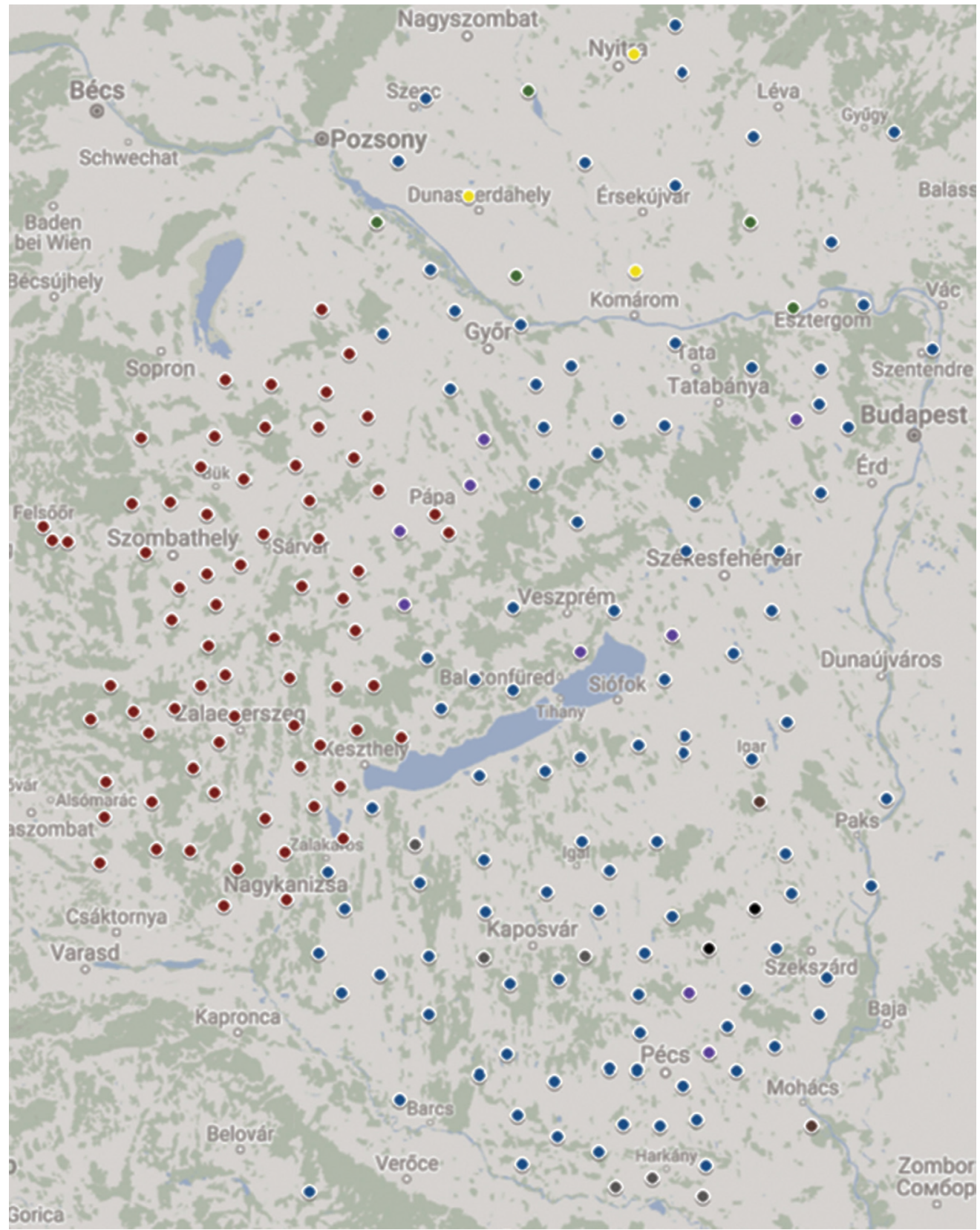




\section{4. térkép}

MNyA. és regionális atlaszok: kenyér (köznyelvi é helyén megjelenő $i$-zés)

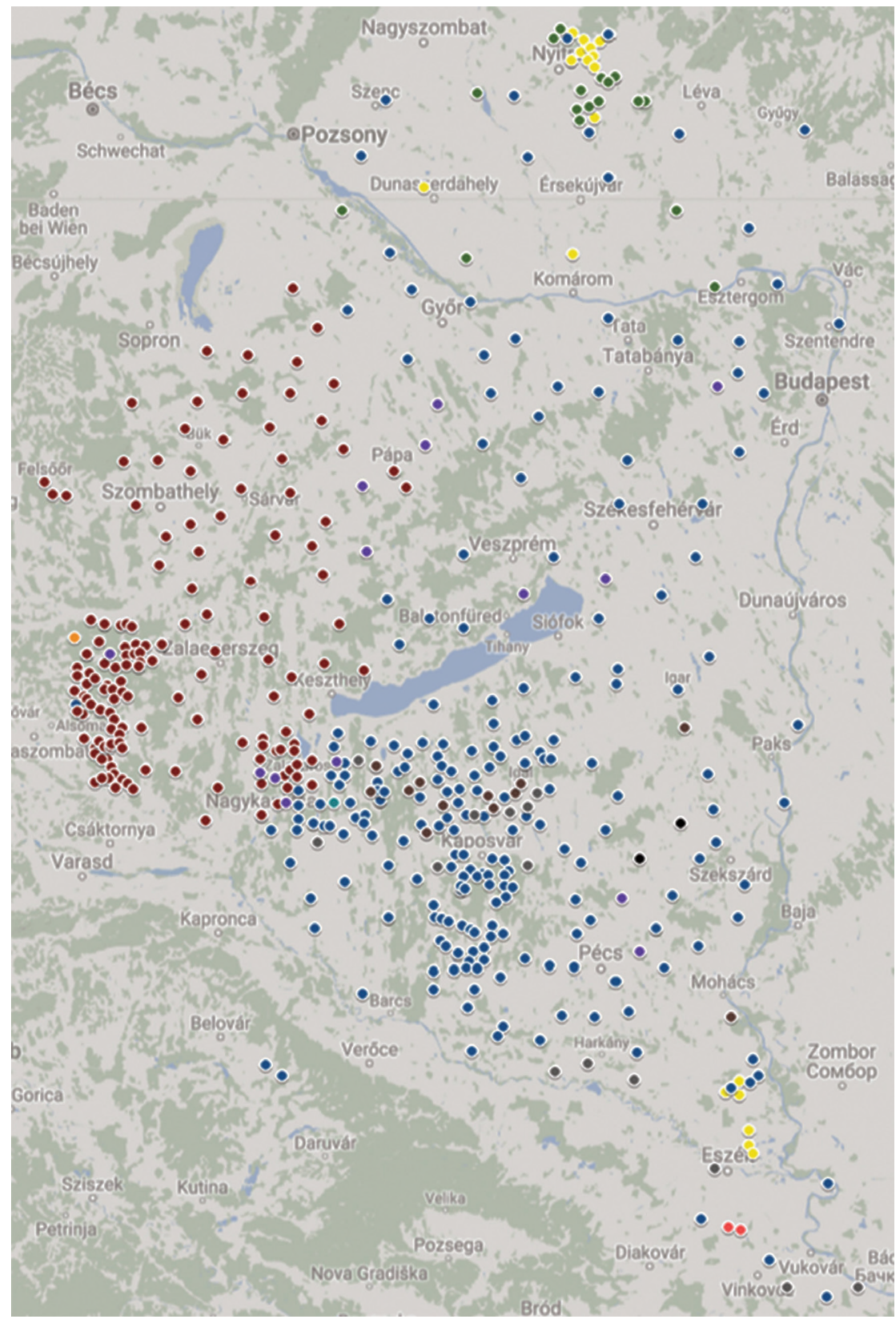




\section{Irodalomjegyzék}

Deme 1999 = Deme LÁszLó,

Kincsesbánya - vagy rozsdatemető? Magyar Nyelvjárások, 37 (1999), 131-133.

Deme 2004 = Deme LÁSZLó,

Üdvözlet, in: Sajtos József, Sárvíz menti nyelvatlasz, Budapest, 2004, 5.

Hegedüs $2004=$ Hegedüs ANDrea

Az egyesített nyelvatlaszok jelentőségéről, in: P. Lakatos Ilona - T. KÁrolyi Margit (szerk.),

Nyelvvesztés, nyelvjárásvesztés, nyelvcsere, Budapest, 2004, 178-181.

HEGEDÜs $2008=$ HEGEdÜs ANDREA,

Nyelvföldrajzi vizsgálatok a romániai magyar nyelvterületen az egyesített atlaszok felhasználásával. Doktori disszertáció. ELTE BTK, Budapest, 2008.

IMRE 1971 = IMRE SAMU,

A mai magyar nyelvjárások rendszere, Budapest, 1971.

JBarA. = PenAVIN OlgA,

A jugoszláviai Baranya magyar tájnyelvi atlasza, Újvidék, 1969.

JuHÁsz 2007 = JuHÁsz Dezső,

Merre tovább, magyar nyelvföldrajz? in: ZeLLiger ErzséBET (szerk.), Nyelv, területiség, társadalom. A 14. Élőnyelvi Konferencia (Bük, 2006.október 9-11.) előadásai, Budapest, 2007, 33-43.

Kiss $2006=$ Kiss JeNö,

Egy új magyar nemzeti nyelvatlasz szükséges voltáról, Magyar Nyelv, 102 (2006), 129-142.

MNyA. = Deme LÁszló - ImRe SAmu (szerk.),

A magyar nyelvjárások atlasza 1-6, Budapest, 1968-1977.

MurA. = PenAvin Olga,

A jugoszláviai Muravidék magyar tájnyelvi atlasza, Budapest, 1966.

NyvA. = SÁNDOR ANNA,

A Nyitra-vidéki magyar nyelvjárások atlasza, Pozsony, 2004.

ÖHA. = VÉGH JózSEF,

Örségi és hetési nyelvatlasz, Budapest, 1959.

SZA. = KirÁly LAJOS, Somogy-zalai nyelvatlasz, Budapest, 2005.

SZABÓ 2018 = SZABÓ PANNA,

Nyelvföldrajzi vizsgálatok a magyar nyelvterület nyugati felén a dialektológiai atlaszok alapján.

Doktori disszertáció. ELTE BTK, Budapest, 2018. DOI: 10.15476/ELTE.2018.071

SzlavA. $=$ Penavin OlgA,

Horvátországi (szlavóniai) magyar nyelvjárási atlasz, Újvidék, 1984.

ZsA. = RÓNAI BÉLA,

Zselici nyelvatlasz. Nyelvföldrajzi vizsgálatok a Zselicben, Pécs-[Budapest], 1993. 